\title{
Pengembangan bahan ajar fisika SMA berbasis masalah menggunakan android untuk meningkatkan kemampuan evaluasi peserta didik
}

\author{
Rizkiani Maghfirotun Istiqomah \\ Program Studi Pendidikan Fisika, FKIP, Universitas Muhammadiyah Purworejo \\ Jl. KH. Ahmad Dahlan No. 3 Purworejo, Jawa Tengah \\ Surat-e: rizkianimaghfirotuni@gmail.com \\ Eko Setyadi Kurniawan \\ Program Studi Pendidikan Fisika, FKIP, Universitas Muhammadiyah Purworejo \\ Jl. KH. Ahmad Dahlan No. 3 Purworejo, Jawa Tengah \\ Surat-e: ekosetyadik@gmail.com

\section{Sriyono} \\ Program Studi Pendidikan Fisika, FKIP, Universitas Muhammadiyah Purworejo \\ Jl. KH. Ahmad Dahlan No. 3 Purworejo, Jawa Tengah \\ Surat-e: srious@yahoo.co.id
}

Penelitian dan pengembangan bahan ajar Fisika berbasis masalah menggunakan aplikasi eXeLearning dan Android ini bertujuan untuk mengetahui kelayakan dan peningkatan kemampuan mengevaluasi peserta didik pada pembelajaran Fisika. Model pengembangan yang digunakan dalam penelitian ini adalah model ADDIE. Sebagai subyek penelitian adalah peserta didik kelas X SMA Negeri 7 Purworejo. Instrumen berupa lembar keterlaksanaan pembelajaran, lembar validasi produk, lembar observasi kemamampuan mengevaluasi, angket respon peserta didik, dan tes hasil belajar. Berdasarkan analisis data diperoleh: validasi kelayakan bahan ajar oleh dosen ahli dan guru Fisika memperoleh skor 3,44 dalam kategori cukup baik, sedangkan uji reliabilitas menunjukkan percentage agreement sebesar 89,52\%, (reliabel); hasil uji kemampuan peserta didik dalam mengevaluasi selama proses pembelajaran diperoleh $\mathrm{N}$-gain 0,359 pada kategori peningkatan sedang. Dapat disimpulkan bahwa bahan ajar Fisika SMA berbasis masalah menggunakaan Android layak dan dapat digunakan sebagai alternatif bahan ajar Fisika.

The research and development of problem-based Physics teaching materials using the eXeLearning and Android application aims to determine the feasibility and improve the students ability to evaluate in learning Physics. This study refers to the ADDIE development model. As the subject of the study were students of class X of SMA Negeri 7 Purworejo. The instruments used in the study were learning implementation sheets, product validation sheets, observation sheets for the ability to evaluate, student questionnaire responses, and learning outcome tests. Based on the data analysis of the study obtained: the feasibility validation of teaching materials by expert lecturers and Physics teachers scored 3.44 in the fairly good category, while reliability testing showed a percentage agreement of $89.52 \%$, (reliable); the test results of students' ability in evaluating during the learning process obtained $\mathrm{N}$-gain 0.359 on the medium improvement category. It can be concluded that the High School Physics teaching materials based on problems use Android appropriately and can be used as an alternative to Physics teaching materials.

Kata kunci: Bahan ajar, eXe-Learning, berbasis masalah, kemampuan mengevaluasi

\section{Pendahuluan}

Pendidikan merupakan upaya sadar yang berperan penting bagi kehidupan manusia karena dengan pendidikan dapat mengembangkan potensi seseorang. Dalam kurikulum 2013 disebutkan bahwa standar kompetensi lulusan merupakan kriteria dan kualifikasi kemampuan lulusan yang mencakup sikap, pengetahuan, dan ketrampilan [1].

Peran guru sangat dibutuhkan dalam proses perbaikan mutu pendidikan melalui pengembangan kurikulum yang disusun oleh pemerintah, melihat kurikulum yang diterapkan saat ini yaitu kurikulum 2013 menuntut peserta didik untuk memiliki kemampuan berpikir tingkat 
tinggi. Kemampuan berfikir tingkat tinggi mencakup tiga level, yaitu menganalisis, mengevaluasi dan mencipta [2].

Beragam masalah dijumpai dalam proses pembelajaran Fisika, salah satunya motivasi peserta didik yang relatif rendah, pembelajaran berlangsung terkesan monoton dan cenderung membosankan [3]. Masalah lain yang dihadapi adalah kesulitan dalam menguasai konsep, kemampuan berpikir kritis, dan kurang aktif dalam pembelajaran. Buku-buku Fisika yang digunakan saat ini belum mengarahkan peserta didik untuk bisa belajar mandiri dalam perumusan masalah, menyusun hipotesis, analisis data, pengujian hipotesis, serta menarik kesimpulan [4].

Sesuai dengan perkembangan teknologi, peserta didik tidak akan dapat terlepas dari alat komunikasi seperti Android. Android dapat dimanfaatkan dalam proses pembelajaran sebagai bentuk kreativitas guru dalam mengikuti pola kebiasaan peserta didik dalam menggunakan handphone dengan mengarahkan pemanfaatan teknologi ke arah yang positif. Pengaruh teknologi pada bidang pendidikan salah satunya dapat dilihat pada perkembangan bahan ajar yang dikembangkan tidak hanya berupa bahan ajar cetak, tapi juga berupa bahan ajar elektronik. Pemanfaatan Android dengan mempertimbangkan kondisi nyata yang terjadi pada pembelajaran Fisika saat ini. Sistem Android yang ada pada smartphone dapat menjadi salah satu alternatif dalam pembelajaran karena memudahkan guru menguasai, memahami dan menggunakannya, peserta didik juga akan lebih termotivasi dan terdorong untuk belajar Fisika [5].

Proses pembelajaran yang hanya memanfaatkan bahan ajar berupa LKS dan buku cetak saja akan terkesan monoton dan membosankan, sehingga berpengaruh terhadap kemampuan berpikir peserta didik. Kemampuan peserta didik dalam mengevaluasi yang merupakan salah satu ranah kognitif kemampuan berpikir tingkat tinggi, belum diasah dan dikembangkan secara optimal.

Tujuan pembelajaran akan tercapai apabila guru dapat mengembangkan proses pembelajaran dengan strategi pembelajaran dan bahan ajar yang tepat dan bervariasi. Guru harus melibatkan peran serta Peserta didik secara aktif dalam proses pembelajaran melalui pemecahan masalah kontekstual, sehingga kemampuan berpikir peserta didik dapat terasah dan pembelajaran tidak terkesan membosankan.

Berdasarkan latar belakang di atas, telah dilakukan penelitian pengembangan bahan ajar yang Fisika SMA berbasis masalah menggunakan Android, yang diharapkan dapat digunakan sebagai alternatif bahan ajar yang inovatif sesuai perkembangan teknologi serta diharapkan dapat meningkatkan kemampuan peserta didik dalam mengevaluasi.

\section{Kajian Pustaka}

\section{Pembelajaran Fisika}

Kegiatan belajar merupakan rangkaian kegiatan untuk memperoleh informasi dari lingkungan yang tersusun secara terencana [6]. Proses tersebut dimaksudkan untuk meningkatkan pengetahuan dan keterampilan peserta didik. Pembelajaran tidak hanya menghasilkan atau menciptakan sesuatu tetapi juga menyesuaikan, memperluas, dan memperdalam pengetahuan.

Aspek pengetahuan, proses, dan sikap dikembangkan dalam pelajaran Fisika yang berisi fakta, konsep, pinsip, hukum dan teori, sebagai produk ilmiah dari Fisika [7]. Fisika sebagai proses ilmiah berisi ketrampilan proses sains yang menghasilkan produk ilmiah, cara ini dikenal sebagai metode ilmiah (scientific methode) yang memiliki beberapa langkah yaitu perumusan masalah, menyusun hipotesis, eksperimen, analisis data, dan kesimpulan.

\section{Strategi Pembelajaran Berbasis Masalah (SPBM)}

Strategi Pembelajran adalah perencanaan awal mengenai pengajaran atau tanggung jawab secara spontan di dalam pembelajaran, yang mana memberikan umpan balik kepada peserta didik [6]. Merancang kegiatan pembelajaran dapat dilakukan dengan mengembangkan strategi pembelajaran untuk menciptakan iklim kelas yang kondusif serta dapat meningkatkan efektivitas dan efisiensi proses pembelajaran. Pada hakekatnya pembelajaran harus memberikan makna tidak sekedar memahami dan menguasai namun memberikan pemahaman tentang bagaimana sesuatu hal dapat terjadi.

Tujuan strategi pembelajaran berbasis masalah yaitu menumbuhkan sikap ilmiah. Menurut ahli SPMB memiliki 6 tahapan yaitu: latar belakang masalah, perumusan masalah, penyusunan hipotesis, pengumpulan data, pengujian hipotesis, solusi [8].

\section{Bahan Ajar}

Dalam kegiatan belajar mengajar bahan ajar turut mendukung proses pembelajaran yang dapat berbentuk bahan ajar cetak maupun non cetak. Bahan ajar merupakan rangkaian materi pembelajaran yang disusun secara sistematis sehingga membantu pemahaman peserta didik [9].

Sebuah bahan ajar dikatakan baik dan menarik apabila memenuhi karakteristik (1) Self Instructional atau disebut juga pembelajaran secara mandiri, (2) Self Contained, yaitu pembelajaran secara tuntas; (3) bersifat Stand Alone, dikemas dalam satu kesatuan yang utuh; (4) Adaptive yaitu sesuai dengan perkembangan ilmu pengetahuan dan teknologi; dan (5) User Friendly, mudah untuk digunakan baik dalam konsistensi isi dan memiliki format penulisan yang sederhana.

\section{eXe-Learning}

Bahan ajar dapat berupa cetak dan non cetak (berbentuk elektronik). Bahan ajar yang disusun secara baik selain harus jelas diharapkan dapat membantu pemahaman peserta didik dalam pembelajaran di sekolah maupun di luar sekolah [10].

Aplikasi eXe-Learning merupakan program aplikasi terbuka yang dapat digunakan untuk pembuatan bahan ajar 
salah satunya materi Fisika. Bahan ajar yang dirancang dengan eXe tersusun secara hierarki yang mencakup bab, sub bab, dan unit. eXe dapat menyajikan latihan soal, pilihan ganda untuk mengetahui kompetensi peserta didik.

Bahan ajar berbasis masalah menggunakan Android dengan aplikasi eXe-Learning dapat digunakan untuk pembelajaran mandiri guna meningkatkan kemampuan dan pengalaman peserta didik dalam belajar dengan atau tanpa pengawasan dari guru. Penulisan yang sistematis peserta didik dapat memahami bahan ajar dengan cara mereka sendiri dan dapat mengukur seberapa jauh pemahaman mereka terhadap materi yang dipelajari, sehingga peserta didik menjadi lebih tertarik dengan materi yang sedang dipelajari dan lebih menyukai dengan proses pembelajaran Fisika yang berorientasi pada kehidupan sehari-hari.

\section{PhoneGap}

Untuk membangun sebuah aplikasi mobile, salah satunya menggunakan framework yang disebut PhoneGap. PhoneGap tidak seperti aplikasi editor berbasis Graphics User Interface (GUI) namun sebuah arsitektur yang dapat kita pakai untuk membuat aplikasi mobile menggunakan bahasa pemrograman HTML5 [11]. Agar dapat memanfaatkan PhoneGap ini, maka pengguna harus membuat akun PhoneGap terlebih dahulu. PhoneGap akan membantu merubah bahan ajar yang sudah dibuat menggunakan media eXe-Learning ke dalam bentuk aplikasi yang dapat diinstal dan digunakan pada HP Android.

\section{Kemampuan Mengevaluasi}

Kemampuan mengevaluasi merupakan salah satu aspek pada kemampuan berpikir tingkat tinggi, yaitu kemampuan untuk mengambil keputusan berdasarkan kriteria dan atau standar berupa kualitas, efektivitas, efisiensi, dan konsistensi [2]. Kemampuan mengevaluasi yang termasuk dalam HOTS dibagi dua indikator yaitu kemampuan memeriksa dan kemampuan mengkritik [2].

Pengambilan keputusan berdasarkan kriteria internal dan eksternal termasuk dalam kategori kemampuan evaluasi, meskipun tidak selalu bersifat evaluatif

Perbedaan utama antara mengevaluasi dan keputusankeputusan lain yang dibuat peserta didik adalah penggunaan standar-standar performa dengan kriteriakriteria yang jelas. Tabel 1 menunjukkan dimensi kemampuan mengevaluasi.

Tabel 1. Dimensi Kemampuan Mengevaluasi

\begin{tabular}{|c|c|c|}
\hline $\begin{array}{l}\text { Kategori dan } \\
\text { Proses Kognitif }\end{array}$ & Istilah Lain & Definisi \\
\hline \multicolumn{3}{|c|}{$\begin{array}{l}\text { Mengevaluasi - mengambil keputusan berdasarkan kriteria } \\
\text { dan atau standar }\end{array}$} \\
\hline Memeriksa & $\begin{array}{l}\text { Mengkoordi } \\
\text { nasi, } \\
\text { Mendeteksi, } \\
\text { Memonitor, } \\
\text { Menguji }\end{array}$ & $\begin{array}{l}\text { Menemukan kesalahan dari } \\
\text { suatu proses atau produk; } \\
\text { menentukan adanya } \\
\text { konsistensi internal dari } \\
\text { suatu produk; menemukan } \\
\text { efektivitas suatu prosedur } \\
\text { yang dipraktikan. }\end{array}$ \\
\hline
\end{tabular}

\begin{tabular}{|c|c|c|}
\hline $\begin{array}{c}\text { Kategori dan } \\
\text { Proses Kognitif }\end{array}$ & Istilah Lain & Definisi \\
\hline Mengkritik & Menilai & $\begin{array}{l}\text { Menemukan kesalahan dari } \\
\text { suatu produk dan kriteria } \\
\text { eksternal; } \\
\text { adanya menentukan } \\
\text { ekesternal dari suatu } \\
\text { produk; menemukan solusi } \\
\text { untuk menyelesaikan } \\
\text { masalah. }\end{array}$ \\
\hline
\end{tabular}

\section{Metode Penelitian}

Penelitian ini merupakan penelitian pengembangan bahan ajar Fisika kelas X SMA. Sebagai subyak penelitian adalah peserta didik kelas X SMA Negeri 7 Purworejo, penelitian dilaksanakan bulan Januari hingga Agustus 2018.

Langkah pengembangan mengacu pada model ADDIE meliputi: Analysis, berupa analisis kebutuhan peserta didik dan guru terhadap bahan ajar; Design, perancangan produk meliputi rencana, desain produk, dan uji produk; Development, dilakukan untuk merancang bahan ajar yang hendak digunakan dalam pembelajaran; Implementation, yaitu penerapan produk dalam kegiatan pembelajaran; Evaluation, pendidik melakukan evaluasi terhadap program pembelajaran yang telah dilaksanakan dan evaluasi hasil belajar [12].

Tabel 2 menyajikan tahap, sasaran dan instrumen penelitian

Tabel 2. Tahap, sasaran, dan instrumen

\begin{tabular}{lll}
\hline \multicolumn{1}{c}{ Tahap } & \multicolumn{1}{c}{ Sasaran } & \multicolumn{1}{c}{ Instrumen } \\
\hline Analysis & Analisis kebutuhan & Lembar \\
& pembelajaran & wawancara \\
& Observasi kemampuan & Lembar \\
& mengevaluasi awal & Observasi dan \\
& Rancangan bahan ajar & soal pre-test \\
Design & Validasi & Lembar \\
Development & & validasi \\
& Respon peserta didik & Angket \\
Implementation & Observasi keterlaksanaan & Lembar \\
& pembelajaran & observasi \\
& Observasi kemampuan & Lembar \\
& mengevaluasi akhir & Observasi \\
& Hasil belajar & Soal post-test \\
& Respon peserta didik & Angket \\
& Bahan ajar Fisika & - \\
\hline
\end{tabular}

Langkah analisis sehingga diperoleh data penelitian melalui tahapan :

\section{Analisis Lembar Validasi Bahan Ajar}

Analisis lembar validasi bahan ajar menggunakan uji reliabilitas dan uji validitas. Uji reliabilitas mengandung maksud keajegan dari instrumen yang digunakan untuk memperoleh data penelitian. Metode pengujian reliabilitas menggunakan Percentage Agreement (PA) yang merupakan persentase kesesuaian nilai antara penilai pertama dan kedua terhadap instrumen, digunakan untuk mengukur keterlaksanaan pembelajaran selama 
menggunakan produk. PA dapat ditentukan dengan persamaan (1).

$$
P A=\left(1-\frac{A-B}{A+B}\right) \times 100 \%
$$

Instrumen dikatakan reliabel jika nilai $\mathrm{PA} \geq 75 \%$ [13].

Uji validitas diperlukan untuk mengukur tingkat kevalidan bahan ajar. Uji validitas dapat dihitung menggunakan persamaan (2).

$$
\text { Persentase }(\%)=\frac{\sum f m}{\sum f a} \times 100 \%
$$

Hasil persentase ini kemudian diubah ke dalam bentuk, nilai. Skala penilaian ini dianalogikan sama dengan skala skor rentang 1-4, sehingga tingkat kelayakan instrumen dapat diketahui dengan persamaan (3) [14].

$$
\text { Nilai }=\text { persentase } \times \text { skor tertinggi }
$$

Setelah nilai diperoleh selanjutnya dikonversi ke dalam skala yang bersifat kualitatif.

\section{Analisis Data Lembar Keterlaksanaan Pembelajaran}

Pedoman penilaian lembar keterlaksanaan ini menggunakan skala 1-4. Cara menghitung persentase skor lembar keterlaksanaan pembelajaran dihitung menggunakan persamaan 1 kemudian hasil persentase ini diubah ke dalam bentuk kriteria analisis data lembar keterlaksanaan pembelajaran. Adapaun kriteria analisis data lembar keterlaksanaan pembelajaran dapat dilihat pada Tabel 5.

\section{Analisis Data Angket Peserta Didik Terhadap Bahan Ajar Fisika}

Data yang telah diperoleh dihitung kemudian disajikan secara deskripsi persentase. Penyajian deskripsi persentase melalui tabel yang berisi tentang hal-hal yang diukur. Untuk menghitung data angket peserta didik dilakukan dengan menggunakan persamaan (4).

$$
N P=\frac{R}{S M} \times 100 \%
$$

Hasil presentase ini diubah ke dalam bentuk kualitatif.

\section{Analisis Data Tes Hasil Belajar}

Peningkatan kemampuan peserta didik dalam mengevaluasi dapat dilihat melalui hasil belajar dengan menggunakan normalized gain. Normalized gain dicari dengan persamaan (5).

$$
g=\frac{S_{f}-S_{i}}{100-S_{i}}
$$

Hasil perhitungan normalized gain kemudian dikonversikan ke dalam klasifikasi normalized gain, dengan kriteria normalized gain [15]. Adapun pada kriteria normalized gain mencakup tiga kategori yaitu kategori rendah, sedang, dan tinggi.
Berdasarkan hasil normalized gain yang diperoleh dari hasil belajar, selanjutnya dapat dilihat apakah kemampuan peserta didik dalam mengevaluasi dapat meningkat dengan adanya bahan ajar Fisika berbasis masalah menggunakan Android yang dikembangkan.

Problem based secara implisit pada rangkuman materi, latihan soal, dan evaluasi dengan berbagai permasalahan yang harus dikaji dan dipecahkan oleh peserta didik. Integrasi PBR disusun berdasarkan pengalaman dan pengetahuan sehari-hari dan kondisi lingkungan peserta didik.

\section{Hasil Penelitian dan Pembahasan}

\section{Hasil Penelitian}

Setelah dilakukan pengumpulan data melalui penelitian pengembangan bahan ajar Fisika SMA berbasis masalah menggunakan Android dengan tahapan model pengembangan ADDIE, maka diperoleh data-data sesuai tahapan ADDIE yang disajikan sebagai berikut.

\section{Tahap Analisis (Analysis)}

Tahap analisis dilakukan dengan dua metode yaitu wawancara dan observasi yang diperoleh informasi bahwa proses pembelajaran didominasi ceramah dan kegiatan menulis di papan tulis. Metode ini membuat sebagian peserta didik merasa bosan, dan mengantuk di dalam kelas. Selain itu, bahan ajar yang digunakan oleh guru belum bervariasi, karena hanya menggunakan buku cetak dan LKS. Bahan ajar yang digunakan belum dapat mengukur kemampuan peserta didik dalam mengevaluasi, karena masih didominasi oleh soal kognitif tingkat rendah dan belum menggunakan rubrik khusus untuk menilai kemampuan tersebut.

\section{Tahap Perancangan (Design)}

Bahan ajar yang dikembangkan tidak berupa media cetak, melainkan didesain menggunakan aplikasi eXe-Learning yang diterapkan dalam bentuk aplikasi offline pada Android dan menggunakan strategi pembelajaran berbasis masalah (SPBM). Uji kompetesi pada bahan ajar, memuat ranah kognitif rendah sampai ranah $\mathrm{C5}$ atau kemampuan mengevaluasi. Bahan ajar menyajikan berbagai masalah berkaitan dengan impuls dan momentum yang dapat melatih kemampuan peserta didik.

\section{Tahap Pengembangan (Development)}

Pada tahap pengembangan produk diuji dengan validasi ahli media, materi fisika, dan guru mata pelajaran Fisika, penilaian oleh dosen ahli pada aspek kelayakan isi diperoleh skor 41 sehingga memperoleh persentase 78,8\% dengan nilai 3,15 dengan kategori cukup baik. Aspek kebahasaan diperoleh skor 10,5 sehingga memperoleh persentase 87,5\% dengan nilai 3,50 dengan kategori cukup baik. Aspek media diperoleh skor 7,50 sehingga memperoleh persentase $93,8 \%$ dengan nilai 3,75 dengan 
kategori baik. Aspek desain dan tampilan diperoleh skor 12,50 sehingga memperoleh persentase $78,1 \%$ dengan nilai 3,12 dengan kategori cukup baik. Aspek pengoperasian program diperoleh skor 3 sehingga memperoleh persentase $75 \%$ dengan nilai 3,00 dengan kategori cukup baik. Keseluruhan aspek mendapatkan nilai 16,52 sehingga reratanya 3,3 dengan kategori cukup baik. Berikut merupakan diagram hasil uji kelayakan bahan ajar Fisika SMA berbasis masalah menggunakan Android oleh dosen ahli, disajikan pada Gambar 1.

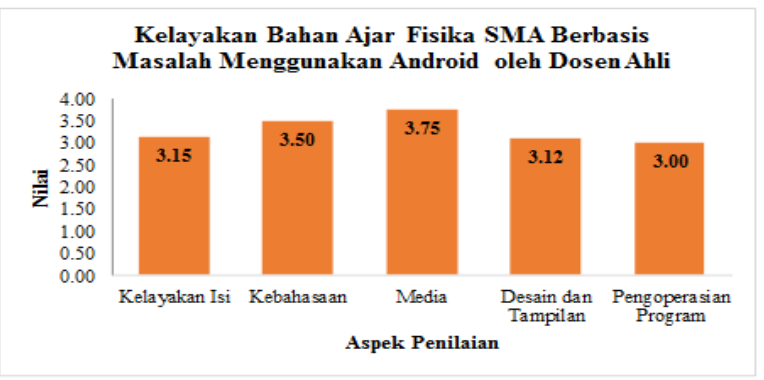

Gambar 1. Kelayakan Bahan Ajar Fisika SMA Berbasis Masalah Menggunakan Android

Penilaian oleh guru Fisika pada aspek kelayakan isi diperoleh skor 45 sehingga memperoleh persentase $86,5 \%$ dengan nilai 3,46 dengan kategori cukup baik. Aspek kebahasaan diperoleh skor 11 sehingga memperoleh persentase 91,7\% dengan nilai 3,67 dengan kategori baik. Aspek media diperoleh skor 8 sehingga memperoleh persentase $100 \%$ dengan nilai 4,00 dengan kategori baik. Aspek desain dan tampilan diperoleh skor 15 sehingga memperoleh persentase $93,8 \%$ dengan nilai 3,75 dengan kategori baik. Aspek kemudahan pengoperasian program diperoleh skor 3 sehingga memperoleh persentase $75 \%$ dengan nilai 3,00 dengan kategori cukup baik. Sehingga keseluruhan aspek mendapatkan nilai 17,88 sehingga reratanya 3,58 dengan kategori baik. Berikut merupakan diagram hasil validasi uji kelayakan bahan ajar Fisika SMA berbasis masalah menggunakan Android oleh guru Fiska disajikan pada Gambar 2.

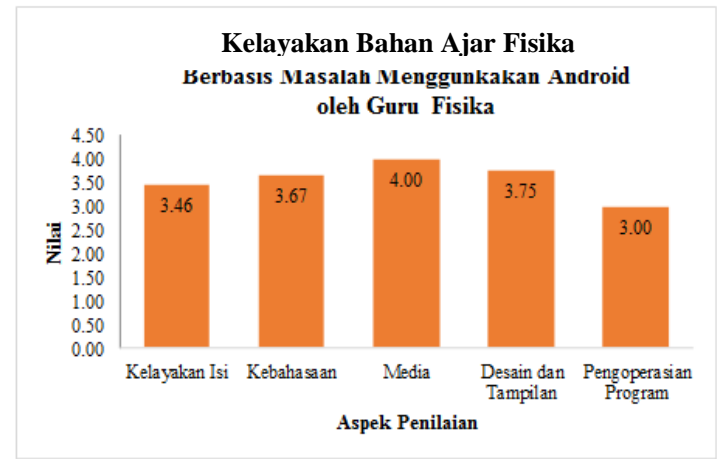

Gambar 2. Hasil Uji Kelayakan Bahan Ajar Fisika SMA Berbasis Masalah Menggunakan Android oleh Guru Fisika

\section{Tahap Penerapan (Implementation)}

Hasil peningkatan kemampuan peserta didik dalam mengevaluasi dilihat melalui proses pembelajaran dan hasil belajar peserta didik. Gambar 3 menyajikan aspek pertama kemampuan mengevaluasi pada kategori rendah sebanyak 28 berkurang menjadi 11, sedangkan kemampuan pada kategori tinggi meningkat dari 8 menjadi 25 peserta didik, aspek kedua kemampuan mengevaluasi pada kategori rendah sebanyak 29 berkurang menjadi 9, sedangkan kemampuan pada kategori tinggi meningkat dari 7 menjadi 27 peserta didik, aspek ketiga kemampuan mengevaluasi pada kategori rendah sebanyak 31 berkurang menjadi 14, sedangkan kemampuan pada kategori tinggi meningkat dari 5 menjadi 22 peserta didik, aspek keempat kemampuan mengevaluasi pada kategori rendah sebanyak 31 berkurang menjadi 14, sedangkan kemampuan pada kategori tinggi meningkat dari 5 menjadi 20 peserta didik, aspek kelima kemampuan mengevaluasi pada kategori rendah sebanyak 32 berkurang menjadi 16, sedangkan kemampuan pada kategori tinggi meningkat dari 4 menjadi 20 peserta didik, aspek keenam kemampuan mengevaluasi pada kategori rendah sebanyak 30 berkurang menjadi 17, sedangkan kemampuan pada kategori tinggi me-ningkat dari 6 menjadi 19 peserta didik.

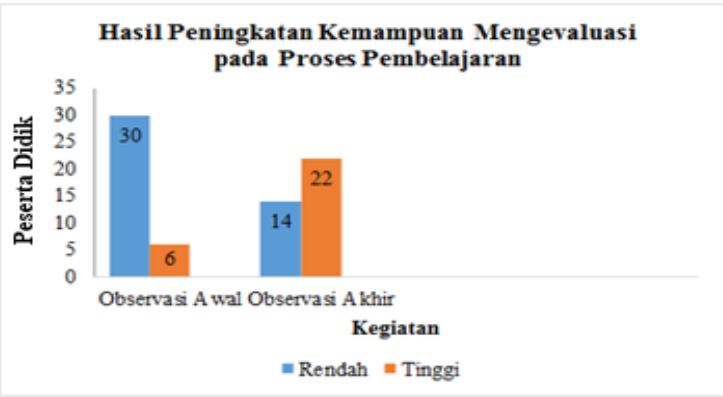

Gambar 3. Kemampuan mengevaluasi pada proses pembelajaran

Peningkatan kemampuan mengevaluasi juga ditinjau dari hasil belajar yang menunjukkan nilai ulangan harian dengan rerata di bawah KKM yaitu 61 dan nilai post-test kedua menunjukkan bahwa semua peserta didik dinyatakan tuntas dengan nilai rerata 75 . Ketuntasan belajar peserta didik memperoleh kriteria gain 0,359 dengan kategori sedang karena nilai gain termasuk dalam kriteria normalized gain $0,3 \geq g<0,7$.

Setelah guru dan peserta didik menggunakan bahan ajar yang dikembangkan, kemudian peneliti membagikan angket respon peserta didik. Aspek penilaian pada angket diantaranya kelayakan isi mendapatkan persentase $85,34 \%$ dengan klasifikasi baik. Aspek kebahasaan mendapatkan persentase 98,68\% dengan klasifikasi sangat baik. Aspek desain mendapatkan persentase $80,79 \%$ dengan klasifikasi baik. Aspek interaksi media mendapatkan persentase $85,94 \%$ dengan klasifikasi sangat baik. Keseluruhan aspek men-dapatkan persentase dengan rerata $87,69 \%$ dengan klasifikasi sangat baik. Data hasil respon peserta didik terhadap bahan ajar Fisika berbasis masalah diperoleh dari 
lembar angket yang diisi oleh 36 peserta didik, dan disajikan pada Tabel 3 .

Tabel 3. Hasil Respon Peserta Didik Tahap Penerapan

\begin{tabular}{clc}
\hline No & Aspek yang Dinilai & Skor yang diperoleh \\
\hline 1. & Kelayakan Isi & 1106 \\
2. & Kebahasaan & 225 \\
3. & Desain & 349 \\
4. & Interaksi Media & 495 \\
& Jumlah & $\mathbf{2 1 7 5}$ \\
& rerata & $\mathbf{5 4 3 , 7 5}$ \\
\hline
\end{tabular}

Keterlaksanaan pembelajaran menggunakan bahan ajar Fisika SMA berbasis masalah menggunakan Android tahap penerapan dievaluasi oleh 3 observer. Observer memberikan evaluasi dan nilai pada lembar observasi yang telah disediakan. Berikut data hasil keterlaksanaan pembelajaran oleh tiga observer dalam 2 kali pertemuan disajikan pada Tabel 4 .

Tabel 4. Hasil Keterlaksanaan Pembelajaran

\begin{tabular}{ccccccc}
\hline \multirow{2}{*}{ No } & \multirow{2}{*}{$\begin{array}{c}\text { Aspek } \\
\text { Keterlaksanaan }\end{array}$} & \multicolumn{5}{c}{ Pertemuan } \\
\cline { 3 - 6 } & & \multicolumn{3}{c}{ I } & \multicolumn{3}{c}{ II } \\
\cline { 3 - 6 } & & $\mathbf{1}$ & $\mathbf{2}$ & $\mathbf{1}$ & $\mathbf{2}$ \\
\hline 1 & Pendahuluan & 11 & 11 & 10 & 11 \\
2 & Kegiatan Inti & 35 & 37 & 36 & 38 \\
3 & Penutup & 3 & 3 & 3 & 3 \\
\hline \multirow{2}{*}{} & Jumlah & $\mathbf{5 8}$ & $\mathbf{4 9}$ & $\mathbf{5 1}$ & $\mathbf{4 9}$ \\
\hline
\end{tabular}

\section{Tahap Evaluasi (Evaluation)}

Tahap evaluasi dilakukan dengan menganalisis bahan ajar yang dikembangkan pada saat tahap implementation. Berdasarkan hasil olah data pada tahap implementation dinyatakan bahan ajar Fisika SMA berbasis masalah menggunakan Android layak diterapkan pada proses pembelajaran. Selain layak, bahan ajar ini ternyata dapat meningkatkan kemampuan peserta didik dalam mengevaluasi.

\section{Pembahasan}

\section{Desain Bahan Ajar}

Bahan ajar Fisika yang dikembangkan di rancang menggunakan model pengembangan ADDIE yang menghasilkan bahan ajar Fisika berbasis masalah menggunakan Android. Bahan ajar yang dikembangkan didesain menggunakan aplikasi eXe-Learning yang diterapkan dalam bentuk aplikasi pada Android. Bahan ajar ini menggunakan Strategi Pembelajaran Berbasis Masalah (SPBM). Uji kompetesi yang ada di dalam bahan ajar, memuat ranah kognitif rendah sampai ranah
C5 atau kemampuan mengevaluasi. Bahan ajar ini adalah media baru bagi guru dan peserta didik karena belum pernah digunakan pada proses pembelajaran sebelumnya..

Bahan ajar Fisika yang dikembangkan menggunakan pendekatan tutorial dan simulasi dalam menyajikan informasi. Pada bahan ajar tersedia pendahuluan berisi kompetensi yang harus dicapai peserta didik. Bahan ajar elektronik ini berisi kegiatan pembelajaran yang mencakup materi yang harus dikuasai peserta didik, aktivitas peserta didik, penunjang materi, contoh soal, uji kompetensi, dan eksplorasi individu maupun kelompok. Proses validasi materi, validasi media, hingga uji coba terbatas dilakukan pada tahap pengembangan.

\section{Penerapan Bahan Ajar}

Produk bahan ajar yang dihasilkan digunakan untuk mengetahui tanggapan peserta didik peningkatan kemampuan mengevaluasi peserta didik. Setelah divalidasi dan dilakukan uji coba terbatas, bahan ajar digunakan guru dan peserta didik dalam proses pembelajaran (uji coba luas). Selama proses keterlaksanaan pembelajaran, kemampuan mengevaluasi peserta didik diamati oleh observer menggunakan instrumen berupa angket dan tes hasil belajar peserta didik.

Penerapan bahan ajar berbantuan aplikasi Android ini diterapkan dalam kegiatan belajar mengajar sebagai alternatif sumber belajar dan membantu peserta didik memahami materi yang sedang dipelajari. Dalam pelaksanaannya, peserta didik mengakses bahan ajar yang dirancang menggunakan perangkat handphonenya, baik di dalam kelas maupun di luar kelas. Melalui bahan ajar ini peserta didik dapat mengakses materi yang telah dirancang oleh guru dimanapun dan kapanpun.

\section{Kesimpulan}

Berdasarkan hasil penelitian, telah dihasilkan sebuah bahan ajar Fisika SMA kelas $\mathrm{X}$ berbasis masalah menggunakan dalam platform Android. Kelayakan bahan ajar Fisika diperoleh dari hasil validasi ahli dengan skor 3,44 termasuk kategori cukup baik sehingga layak digunakan sebagai alternatif bahan ajar Fisika SMA. Uji reliabilitas menunjukkan PA sebesar $89,52 \%$ termasuk kategori reliabel.

Hasil observasi dan tes hasil belajar Fisika meunjukkan peningkatan kemampuan mengevaluasi peserta didik yang dilaksanakan sebelum dan sesudah pembelajaran menggunakan bahan ajar yang dikembangkan dengan $\mathrm{N}$ gain sebesar 0,359 yang termasuk dalam kategori peningkatan sedang. Hasil belajar peserta didik terjadi peningkatan dengan nilai rerata 77 dari nilai KKM untuk mata pelajaran Fisika sebesar 75 .

Berdasarkan hasil penelitian yang telah dilakukan, bahan ajar Fisika berbasis masalah berbasis Android yang dikembangkan dapat digunakan sebagai alternatif bahan ajar Fisika SMA kelas X. 


\section{Kepustakaan}

[1] Permendikbud No. 20, Standar Kompetensi Lulusan (SKL) jenjang pendidikan dasar dan menengah, 2016.

[2] Krathwohl, D. R., A revision of Bloom's Taxonomy: An Overview. Theory Into Practice. College of Education, The Ohio State University, vol. 41, no 4, 2002, pp. 212-218.

[3] Wasonowati, R. R. T., Redjeki, T., \& Ariani, S. R. D., Penerapan Model Problem Based Learning (PBL) pada Pembelajaran Hukum-Hukum Dasar Kimia Ditinjau dari Aktivitas dan Hasil Belajar Siswa Kelas X IPA SMA Negeri 2 Surakarta Tahun Pelajaran 2013/2014. Jurnal Pendidikan Kimia, 2014, vol. 3, no. 3, 2018, pp. 66-75.

[4] Primadi, M. R., Sarwanto, S., \& Suparmi, S., Pengembangan modul fisika berbasis inkuiri terbimbing untuk meningkatkan kemampuan berpikir kreatif siswa pada materi listrik dinamis. Jurnal Riset dan Kajian Pendidikan Fisika, vol,5, no. 1, 2018, pp. 1-9.

[5] Al-idrus, S. Q. M. J., Aplikasi Android pada Pembelajaran Fisika: Sebuah Solusi Mutakhir Pembelajaran Fisika di Era Global. In Prosiding SNFA (Seminar Nasional Fisika dan Aplikasinya), vol. 2, 2017, pp. 214-221.

[6] Suprihatiningrum, J., Strategi Pembelajaran, Yogyakarta, ArRuzz Media, 2018.

[7] Domi. S., Makalah:"Pembelajaran Fisika Seturut Hakekatnya Serta Sumbangannya Dalam Pendidikan Karakter Siswa". Disajikan dalam Seminar Nasional 2nd Lontar Physics Forum. ISBN: 978-602-8047-80-7. 2013.

[8] Sanjaya, W., Strategi Pembelajaran, Bandung, Kencana Prenadamedia Group, 2014.

[9] Wahyuni, S., Pengembangan Bahan Ajar IPA untuk Meningkatkan Kemampuan Berpikir Kritis Siswa SMP. In Prosiding: Seminar Nasional Fisika dan Pendidikan Fisika, vol. 6, no. 6, 2015.

[10] Husnaini, A. N., Pengembangan Media Pembelajaran Berbasis Android pada Kompetensi Menjelaskan Pemasangan Komponen dan Sirkit PLC untuk SMK. Jurnal Pendidikan Teknik Mekatronika, vol. 6, no. 6, 2016.

[11] Huda, M. K., Tutorial Pembuatan Aplikasi Android Berbasis Phonegap (online). 2017.

Website: (https://mkhuda.com/category/phonegap-framework/, diakses tanggal 4 Januari 2018.

[12] Pribadi, B. A., Model Desain Sistem Pembelajaran, Jakarta, Dian Rakyat, 2010.

[13] Arsanty, V. N. dan Yusman Wiyanto, Pengembangan Perangkat Pembelajaran Fisika Berbasis Model Pembelajaran STS dalam Peningkatan Penguasaan Materi dan Pencapaian Kreativitas Peserta Didik SMA. Jurnal Pendidikan Fisika, vol. 6, no. 1, pp. 27. 2017.

[14] Prastiwi, A., Pengembangan Modul Fisika Berbasis Masalah untuk Meningkatkan High Order Thinking Skills (HOTS) Siswa SMA, Universitas Muhammadiyah Purworejo, 2016.

[15] Hake, Richard R., Analyzing Change/Gain Scores. Dept of Physics. Indiana University. 1999. 